\title{
Return Migration After 30 September 2009 Earthquake in West Sumatra, Indonesia
}

\author{
Syafruddin Karimi \\ Dept. of Economics, Andalas University \\ Kampus Limau Manih, Padang 25163, Indonesia \\ Tel: 62-751-71088Ｅ-mail: syafruddinkarimi@gmail.com
}

Received: January 25, 2017 Accepted: February 14, 2017 Published: February 28, 2017

doi:10.5296/jad.v3i1.10714 URL: http://dx.doi.org/10.5296/jad.v3i1.10714

\begin{abstract}
This article analyzed return migrants associated with the West Sumatra Large-Scale Earthquake on 30 September 2009. A survey of 400 households traced the number of return migrants. Any respondent migrated due to the earthquake belongs to return migrant. This study found the return migrants accounting for almost $37 \%$ because of the disaster. Both men and women migrated because of the earthquake, but more men migrated than women. Married couple migrated more than unmarried. Pekanbaru, the capital of Riau province, is the most famous destination for migration. The education level of return migrants is higher than the stayers. More than $88 \%$ are living from trade, public services, and fishing. Above $50 \%$ is living from trading alone. The return migrants shared a similar employment status with the stayers. Entrepreneurial status is more important for return migrants than for the stayers. Income distribution shows a different pattern between return migrants and the stayers. The return migrants have a more significant part of the maximum income group. The return migrants at the highest income group account for $27 \%$, which is obviously greater than the stayers.
\end{abstract}

Keywords: West Sumatra, earthquake, return migrants, income distribution 


\section{Introduction}

West Sumatra Province is one of the many disaster-prone areas in Indonesia, located on the west coast of the island of Sumatra, and overlooks the Indian Ocean. Residents of West Sumatra in 2010 amounted to 4.8 million, with an average income per person of about $\$ 2,500$. An earthquake with a strength of 7.9 on the Richter scale struck West Sumatra on 30 September 2009. The disaster caused many human casualties and property damage. Material losses include damage to homes, offices, markets, places of worship, education, and shops. The number of human casualties caused by the earthquake reached 9,554 people. The entire number of death, accounts for 1,195 victims and two lost victims. Injured reach as many as 1,803 people. The government evacuated 6554 people because of the earthquake damaged houses (BNPB, 2009).

The earthquake has impacted 10 out of 16 districts and cities in West Sumatra. The district of Tanah Datar reported the largest in the number of total death victims. Padang City reported the second largest in the number of whole death victims. Padang Pariaman District, Pariaman City and the District of Mentawai Islands also reported death victims despite less in numbers. Padang City reported lost victims. The evacuated victims only occurred in the district of Padang Pariaman due to buildings damaged (BNPB, 2009).

The productive capacity damage could negatively lead to regional economic growth, employment, poverty, and income distribution. The damage to buildings and shopping markets hampered productivity, specifically in trading. The damaged road hindered trading between regions within West Sumatra's province (Pranoto et al., 2011). The quake has caused the affected residents moved away to another city, but there are no available data on how many people are moving. Therefore, the study conducted a survey to interview 400 households in Padang during January 2014. This survey followed a random sampling method to select family from every sub-district. A respondent enters the category of return migrant if he or she migrated after the earthquake on 30 September 2009. The study examines the social-economic characteristics of return migrants.

\section{Review of Literature}

The presence of disaster victims, both human and material possessions, affects the economic performance. Disasters affect the financial results through their impact on human and infrastructure. Human casualties and property damage reduce productivity, increase unemployment and raise the level of poverty. The impact of the disaster on population mobility works through the social and economic mechanism. Human casualties and physical damages resulting from disaster discouraged productive activities. A fall in production drove the price level to rise and pushed down consumption and welfare. The goals for reducing unemployment and poverty may be getting more difficult with the impact of the disaster. A worsening economic performance in disaster wedged region may push local labor and capital to flow into another area. The government needs to maintain the macroeconomic stability in the disaster impacted areas (Mechler, 2003). The government needs to minimize the negative consequences of the catastrophe. The relief and reconstruction are substantial and costly for disaster-impacted countries. The international donor is expected to support disaster wedged 
countries for the need of financing. It could develop risk financing arrangements to minimize the vulnerability to natural hazards (Mechler, 2004).

Economists and social sciences have developed various hypotheses about the behavior of individuals who decided to live in disaster-prone areas related to the socioeconomic disruption caused by disasters (Vigdor, 2007). Natural disasters have a negative impact on development, particularly on economic activity. Financial losses due to natural disasters could absorb resource's capacity in enormous portions. The income of a disaster-affected region might not reach the total cost of the recovery, rehabilitation, and reconstruction. The disasters damaged the development during the period. Natural disasters can lead in the negative-sum game. Setbacks due to disasters in a region do not result in economic progress at all in other areas. It can even take the burden. Disaster recovery efforts may weigh on macroeconomic performance and can divert the national budget to restore productive activity in the affected area (Negara \& Bary, 2006).

Post-disaster migration can open opportunities to improve livelihoods. The cost of immigration tends to reduce the moving appeal, while disaster risk tends to encourage people to move. An improved local business performance helped the return migrants. The opposite discouraged the return migrants. The migration income effect depends on a lot of the government incentives for the disaster-damaged businesses recovery. The government incentives determined the business recovery and the economic performance (Vigdor, 2007).

The decision to move depends on the relative benefits of migrating or settling. An improved livelihood may not only result from relocating to another country, but also from staying at home. Staying at home also likely improved livelihoods. The migration experience in a particular country also influenced the migration choice for a destination. The Nicaraguan's migrating experience to Costa Rica changed the decision to migrate after Hurricane Mitch. The past good movement experience encouraged the future migration to the same destination and vice versa. The presence of household owning businesses discouraged the likelihood of migration. Home business owners chose the repair disaster-damaged businesses rather than migrating to another country. Local business's recovery is necessary for improving livelihoods after the disaster (Loebach, 2016).

Difficulty and ease encountered after a catastrophe affecting the decision to migrate. The level of devastation to encourage people to migrate, but the level of resilience prevent people from migrating. Forced migration reflects the severity is high while staying reflect a high degree of resistance. Do Yun (2016) examines the effects of hurricanes Katrina and Rita on the decision to migrate or settle. A disaster made households double victims. The disaster forced families to move and forced their income to fall. Households having income below average experienced more severe environment (Do Yun, 2016). A forced migration could also result from the presence of displaced people and refugees due to environmental and climate changes (Rechkemmer et al., 2016). Ishtiaque (2016) argued that urbanization could associate with a natural disaster. The natural disaster forced the migration of rural population to urban areas as evident from a study in Dhaka City, the capital of Bangladesh. The study found more than $18 \%$ of migration from rural to urban areas resulting from disaster impacted areas. 


\section{Macrothink}

The negative consequences of a catastrophe on rural economic activities forcefully pushed urbanization (Ishtiaque, 2016). In contrast, a study on Indonesia reported a negative relationship between natural disasters and migration rate. The migration cost and local job opportunity increased because of natural disaster, while total earnings and non-business assets decreased. The net effect would lessen the inclination to migrate (Tse, 2011).

Government's treatment of particular groups of people will affect his decision to migrate or not after a natural disaster. Attitude blacks were reluctant to return home to reflect the impact of how the government treats them. Little political trust reduces the desire to go back (Reinhardt, 2015). Repair neighborhoods and housing after disasters also affect the decision to return home or not. The black community after the catastrophe in New Orleans has a little tendency to go back. The low tendency to go home also occurs to the low socioeconomic class people. Home repairs after the disaster influenced the decision to return home. Severe damage due to major disaster requires a high rate of performance to rehabilitate. Advances in restoration, repair, rehabilitation and reconstruction in the affected areas influence the decision of migrants to return home. The return migrants followed an improved infrastructure and social networks. The quality of public services, education, and health services attracted the return of disaster driven migrants. The community institution needs to function normally to attract return migrants (Fussell, Sastry, \& VanLandingham, 2010).

\section{Methods}

The study applied the Slovin-Yamane formula to determine the sample size (Sevilla, Achave, Punsalan, Regala, \& Uriarta, 1992; Yamane, 1967). The formula states that: $n=N / 1+N(e)^{2}$.

Where $\mathrm{n}$ is the sample size; $\mathrm{N}$ is the population size, and e is margin error. The study determined the sample size by using 5\% margin error and the Padang population in 2010. The formula set the sample size 400 households using the population number 833,584. The sample size by sub-districts followed the population distribution. 


\section{Macrothink}

Table 1. The Population Number and Sample Size in Padang City by Sub-Districts

\begin{tabular}{|c|c|c|c|c|}
\hline \multirow{2}{*}{ No. } & \multirow{2}{*}{ Name of Sub-District } & \multicolumn{2}{|c|}{ Total Population } & \multirow{2}{*}{$\frac{\text { Sample Size (households) }}{\text { Number }}$} \\
\hline & & Number & $\%$ & \\
\hline 1 & Bungus Teluk Kabung & 23,200 & 2.8 & 11 \\
\hline 2 & Lubuk Kilangan & 49,127 & 5.9 & 24 \\
\hline 3 & Lubuk Begalung & 106,465 & 12.8 & 51 \\
\hline 4 & Padang Selatan & 57,676 & 6.9 & 28 \\
\hline 5 & Padang Timur & 77,675 & 9.3 & 37 \\
\hline 6 & Kuranji & 126,520 & 15.2 & 61 \\
\hline 7 & Padang Barat & 45,321 & 5.4 & 22 \\
\hline 8 & Padang Utara & 68,810 & 8.3 & 33 \\
\hline 9 & Nanggalo & 57,221 & 6.9 & 27 \\
\hline 10 & Pauh & 59,075 & 7.1 & 28 \\
\hline 11 & Koto Tangah & 162,494 & 19.5 & 78 \\
\hline & Total & 833,584 & 100.0 & 400 \\
\hline
\end{tabular}

Source: Padang in Figures (BPS, 2014).

Table 1 shows the number of population and the formula calculated sample size. The West Sumatra's earthquake on 30 September 2009 impacted all sub-districts in Padang City. Every sub-district has the sample size according to the population proportion. The survey selected household randomly in each sub-district. The study interviewed all 400 households during January 2014. The study identifies the return migrants by asking whether the respondents moved or not in response to the earthquake on 30 September 2009. A return migrant is defined as a respondent who migrated because of the quake on 30 September 2009.

\section{Return Migrants: A Survey Findings from West Sumatra}

Table 2 shows the number of return migrants by gender. The return migrants accounted for about $37 \%$. Migrants consist of men and women, but men have a greater proportion than women. The West Sumatra province is the home for the Minangkabau indigenous community. The tradition encouraged men to migrate in their lifecycle. An ultimate goal of migration is to return home when sufficient knowledge and human capital accumulated (Kahn, 1980; Nasroen, 1971). Although the Minangkabau tradition does not encourage women's migration, the value has changed. Women are no longer staying at home guarding the clan treasure, but they now take the opportunity to migrate as well as men. The survey also showed the important role of women as return migrants. 
Table 2. Respondents by Return Migrants and Marital Status (Household)

\begin{tabular}{lrrrr}
\hline \multirow{2}{*}{ Gender } & \multicolumn{3}{c}{ Return Migrant } & \multicolumn{2}{c}{ Total } \\
\cline { 2 - 4 } Female & \multicolumn{2}{c}{ Yes } & 47 \\
& 110 & $(29.9)$ & $(157$ \\
Nale & $(70.1)$ & 99 & 243 \\
& 144 & $(40.7)$ & $(100.0)$ \\
\hline \multirow{2}{*}{ Total } & $(59.3)$ & 146 & 400 \\
& 254 & $(36.5)$ & $(100.0)$ \\
\hline
\end{tabular}

Source: Padang Household Survey, 2014.

Figures in parentheses are in percentage.

Table 3 showed the number of return migrants and the destination when they migrated. The survey found that Pekanbaru is the most famous destination. Pekanbaru is the capital of Riau province, a neighboring province of West Sumatra. The distance is about $300 \mathrm{~km}$ from Padang to Pekanbaru. The migration to Pekanbaru is very common for the people of West Sumatra. Since the local autonomy, the rich province of Riau expanded its economy that attracted the migrant flow from neighboring regions, particularly West Sumatra. The return migrants from Pekanbaru accounted for $68.5 \%$, and from Jakarta 20.5\%. Jakarta is also an important destination for migrants from Padang, reflecting the role of Jakarta as the capital of Indonesia.

Table 3. Number of Sampled Households by Destination to Migrate and Return Migrant (\%)

\begin{tabular}{lrrrr}
\hline \multirow{2}{*}{ Destination } & \multicolumn{2}{c}{ Return Migrant } & \multicolumn{2}{c}{ Total } \\
\cline { 2 - 4 } & No & \multicolumn{2}{c}{ Yes } & \\
\hline Pekanbaru & & & 68.5 & 25.0 \\
Medan & & 5.5 & 2.0 \\
Lampung & & 5.5 & 2.0 \\
Jakarta & & 20.5 & 7.5 \\
Staying & & & 63.5 \\
Total & 100.0 & 100.0 & 100.0 \\
\hline
\end{tabular}

Source: Padang Household Survey, 2014.

Table 4 shows the importance of ethnicity for return migrants. All Indonesian indigenous ethnic groups live in West Sumatra, but the survey only found Minangkabau, Malay, Batak, Javanese, Sundanese, India, and Chinese. The Minangkabau is the largest group in the survey, in the return migrants, and in the stayers. Minangkabau, the native of West Sumatra, has the migration tradition (Murad, 1980; Naim, 1973). 


\section{Macrothink}

Table 4. Respondents by Return Migrant and Ethnicity (\%)

\begin{tabular}{lrrrr}
\hline \multirow{2}{*}{ Ethnicity } & \multicolumn{3}{c}{ Return Migrant } & \multicolumn{2}{c}{ Total } \\
\cline { 2 - 4 } & No & \multicolumn{2}{c}{ Yes } & 92.5 \\
\hline Minangkabau & 91.3 & 2.1 & 91.7 \\
Malay & .4 & 4.1 & 1.0 \\
Batak & 3.6 & .7 & 3.8 \\
Javanese & 2.4 & & 1.8 \\
Sundanese & .4 & & .3 \\
Chinese & .4 & .7 & .3 \\
Indian & 1.6 & 100.0 & 1.3 \\
Total & 100.0 & & 100.0 \\
\hline
\end{tabular}

Source: Padang Household Survey, 2014

Table 5 shows the surveyed households by return migrants and the stayers. The married families play a greater part than single. The surveyed households accounted for almost $70 \%$ married families and less than $30 \%$ single. The return migrants and the stayers display the importance of married families, but married families are more important for return migrants than for the stayers. Marital status matters for return migrants.

Table 5. Respondents by Return Migrants and Marital Status (\%)

\begin{tabular}{lcrrr}
\hline \multirow{2}{*}{ Marital Status } & \multicolumn{3}{c}{ Return Migrant } & \multirow{2}{*}{ Total } \\
\cline { 2 - 4 } Single & No & \multicolumn{2}{c}{ Yes } & 30.3 \\
Married & 37.4 & 17.8 & 69.8 \\
Total & 62.6 & 82.2 & 100.0 \\
\hline
\end{tabular}

Source: Padang Household Survey, 2014.

Table 6 shows the importance of educational for return migrants. The part of high school and university education almost reached $87 \%$. The part of elementary school and without formal education accounted for less than $14 \%$. The part of secondary high school reached above $43 \%$. The part of higher education reached almost $32 \%$. The part of return migrants at higher education are larger than the part of stayers in higher education. The return migrants are also higher for elementary and first high schools. On the contrary, the return migrants are smaller than the stayers for education below the primary level and secondary high. The results show that better education is essential for return migrants. 


\section{Macrothink}

Table 6. Respondents by Return Migrant and Education Level (\%)

\begin{tabular}{|c|c|c|c|}
\hline \multirow{2}{*}{ Education Level } & \multicolumn{2}{|c|}{ Return Migrant } & \multirow{2}{*}{ Total } \\
\hline & No & Yes & \\
\hline Not elementary school & 3.9 & 2.1 & 3.3 \\
\hline Elementary school & 9.4 & 11.0 & 10.0 \\
\hline First High School & 10.2 & 13.7 & 11.5 \\
\hline Secondary High School & 46.5 & 38.4 & 43.5 \\
\hline University & 29.9 & 34.9 & 31.8 \\
\hline Total & 100.0 & 100.0 & 100.0 \\
\hline
\end{tabular}

Source: Padang Household Survey, 2014

Table 7 shows the condition of the respondent according to the main economic activity. All respondent groups show the same structural economic pattern. The most significant activity comes from trading, then public services and fishing. Padang as the capital of West Sumatra province relies on trading and public sector working. As the area is on the Indian Ocean coast, fishing is also an important livelihood for the citizens of the city of Padang. Fishery's sector shows the third most important of all respondents. Trade, public services, and fishing provide a source of livelihood for over $88 \%$ of all respondents. The survey also found that respondents working in the agricultural sector, but the amount is less than $3 \%$ of those surveyed. Housekeepers give livelihood portions larger than as farmers. Among the respondents also found the number of pensioners and the unemployed, but the proportion is tiny.

Table 7. Return Migrant by Main Economic Activity (\%)

\begin{tabular}{lrrrr}
\hline \multirow{2}{*}{ Main economic activity } & \multicolumn{2}{c}{ Return Migrant } & Total \\
\cline { 2 - 3 } & No & \multicolumn{2}{c}{ Yes } & 2.8 \\
\hline Farming & 3.1 & 2.1 & 52.8 \\
Trading & 52.0 & 54.1 & 24.0 \\
Public services & 23.6 & 24.7 & 11.8 \\
Fishing & 13.0 & 9.6 & 5.0 \\
Retirement & 3.9 & 6.8 & 3.3 \\
Housekeeping & 3.5 & 2.7 & .5 \\
Unemployed & .8 & & 100.0 \\
Total & 100.0 & 100.0 & \\
\hline
\end{tabular}

Source: Padang Household Survey, 2014.

Table 8 shows the return migrant by employment status. The most important employment status is working as labor. The proportion of labor accounted for larger than $60 \%$. Working as self-employed accounted for greater than $28 \%$ of employment. Employer contributed almost $10 \%$ to employment status. The return migrants are similar to the stayers in the importance of employment status. Working as labor is more valuable than other jobs either for return 
migrants or the stayers. The importance of self-employed and employer is equal for return migrants to the stayers. Self-employed and employer are more important for return migrants than for stayers, but labor status is less important for return migrants than for the stayers.

Table 8. Households by Return Migrants and Employment Status (\%)

\begin{tabular}{lcrr}
\hline \multirow{2}{*}{ Employment status } & \multicolumn{2}{c}{ Return Migrant } & \multirow{2}{*}{ Total } \\
\cline { 2 - 4 } & No & Yes & 28.2 \\
Self-employed & 26.2 & 31.7 & 9.6 \\
Employer & 7.9 & 12.4 & 62.2 \\
Labor & 65.9 & 55.9 & 100.0 \\
Total & 100.0 & 100.0 & \\
\hline
\end{tabular}

Source: Padang Household Survey, 2014

Table 9 shows the importance of income level for return migrants and the stayers. The income level consists of three groups. First, household income below Rp3million a month belongs to the low-income group. Second, household income between Rp3 to Rp5million belongs to the middle-income group. Third, household income above Rp5million a month belongs to the highest income group. More than $49 \%$ belong to the low-income group. Almost $23 \%$ belong to the highest income group. The middle-income group accounted for $28 \%$.

Table 9. Respondents by Return Migrant and Income (\%)

\begin{tabular}{llll}
\hline \multirow{2}{*}{ Household Income (Rp'000/month) } & \multicolumn{2}{l}{ Return Migrant } & Total \\
\cline { 2 - 3 } & No & Yes & 49.3 \\
\hline$<3,000$ & 48.8 & 50.0 & 28.0 \\
$3,000-5,000$ & 31.1 & 22.6 & 22.8 \\
$>5,000$ & 20.1 & 27.4 & 100.0 \\
Total & 100.0 & 100.0 & \\
\hline
\end{tabular}

Source: Padang Household Survey, 2014

Rp: Indonesian's currency. US $\$ 1=\mathrm{Rp} 13,000$.

The return migrants are different from the stayers in the pattern of income distribution. A half of return migrants belong to the low-income group. The stayers accounted for about $49 \%$ in the lowest-income group. At the middle-income group, the return migrants accounted for almost $23 \%$ and stayers greater than $31 \%$. In contrast, the return migrants accounted for larger than $27 \%$ at the highest income level. The return migrants have a larger part in the maximum income group than the stayers. 


\section{Conclusion}

This article analyzed return migrants associated with the West Sumatra Large-Scale Earthquake on 30 September 2009. A survey of 400 households traced the number of return migrants. Any respondent migrated due to the earthquake belongs to return migrant. This study found the return migrants accounting for almost $37 \%$ because of the disaster.

Both men and women migrated because of the earthquake, but more men migrated than women. The Minangkabau tradition encouraged more men to migrate than women. Married couple migrated more than unmarried. Pekanbaru, the capital of Riau province, is the most famous destination for migration. The destination is important not only for migration because of the disaster.

Better education associates with return migrants. The education level of return migrants is higher than the stayers. In higher education, the proportion of return migrants is greater than the stayers. The proportion of return migrants is smaller than the stayers at the lowest education level.

The return migrants follow the same source of living with the stayers. More than $88 \%$ are living from trade, public services, and fishing. Above $50 \%$ is living from trading alone. Below 3\% is working in agriculture, and farming is less significant than housekeeping. A tiny number of pensioners and the unemployed, appeared among the households.

The return migrants shared a similar employment status with the stayers. The most important employment status is working as labor. Labor is equally valuable for return migrants and the stayers. The importance of self-employed and employer is equal for return migrants to the stayers. Entrepreneurial status is more important for return migrants than for the stayers, but labor status is more important for stayers than for the return migrants.

Income distribution shows a different pattern between return migrants and the stayers. A significant number of households belong to lower income group. The return migrants account for a half of the lower income group which is slightly greater than the stayers. At the middle-income group, the return migrants accounted for almost $23 \%$, which is smaller than the stayers. The return migrants have a more significant part of the maximum income group. The return migrants at the highest income group account for $27 \%$, which is obviously greater than the stayers.

\section{References}

BNPB. (2009). West Sumatra and Jambi natural disasters : damage, loss, and preliminary needs assessment. Jakarta: Indonesia. Badan Nasional Penanggulangan Bencana.

BPS. (2014). Padang in Figures. Padang: Badan Pusat Statistik.

Do Yun, S. W., Brigitte S. (2016). The Day After the Disaster: Forced Migration and Income Loss after Hurricanes Katrina and Rita. Journal of Regional Science, 56(3), 420-441. https://doi.org/10.1111/jors. 12250

Fussell, E., Sastry, N., \& VanLandingham, M. (2010). Race, socioeconomic status, and return 
migration to New Orleans after Hurricane Katrina. Population and Environment, 31(1-3), 20-42. https://doi.org/10.1007/s11111-11009-10092-11112.

Ishtiaque, A. N., \& Nurul, I. (2016). Household-level disaster-induced losses and rural-urban migration: Experience from world's one of the most disaster-affected countries. Natural Hazards. https://doi.org/10.1007/s11069-016-2690-5.

Kahn, J. S. (1980). Minangkabau Social Formations: Indonesian Peasants and the World-Economy. Cambridge University Press. https://doi.org/10.1017/CBO9780511557552

Loebach, P. (2016). Household migration as a livelihood adaptation in response to a natural disaster. Nicaragua and Hurricane Mitch. Population \& Environment, 38(2), 185-206. https://doi.org/10.1007/s11111-016-0256-9

Mechler, R. (2003). Macroeconomic Impacts of Natural Disasters. Retrieved fron https://www.researchgate.net/profile/Reinhard_Mechler/publication/237643342_Macroecono mic_Impacts_of_Natural_Disasters/links/0deec5290c8ead3c74000000.pdf.

Mechler, R. (2004). Natural Disaster Risk Management and Financing Disaster Losses in Developing Countries: Verlag Versicherungswirtschaft.

Murad, A. (1980). Merantau: outmigration in a matrilineal society of West Sumatra: Dept. of Demography, Australian National University.

Naim, M. (1973). Merantau: Gadjah Mada University Press.

Nasroen, M. (1971). Dasar falsafah adat Minangkabau. Bulan Bintang.

Negara, S. D., \& Bary, P. (2006). Bencana Alam: Dampak dan Penanganan Sosial Ekonomi. Masyarakat Indonesia, 34(1), 115-134.

Pranoto, S., Sugeng, S., Kayo, R., Karimi, S., Fauzan, Ermiza, Z., et al. (2011). Lessons Learned Rehabilitation and Reconstruction West Sumatra, September 30th, 2009 Earthquake: Building Back Better. Jakarta: Gramedia.

Rechkemmer, A., O'Connor, A., Rai, A., Decker Sparks, J. L., Mudliar, P., \& Shultz, J. M. (2016). A complex social-ecological disaster: Environmentally induced forced migration. Disaster Health, 3(4), 1-9. https://doi.org/10.1080/21665044.2016.1263519

Reinhardt, G. Y. (2015). Race, Trust, and Return Migration. Political Research Quarterly, 68(2), 350-362. https://doi.org/10.1177/1065912915575790

Sevilla, C. G., Achave, J. A., Punsalan, T. G., Regala, B. P., \& Uriarta, G. G. (1992). Research Methods. Manila: Rex Bookstore, Inc.

Tse, C. W. (2011). Do Natural Disasters Really Lead to Forced Migration? Evidence from Indonesia. Retrieved from https://ssrn.com/abstract=1906556.

Vigdor, J. L. (2007). The Katrina Effect: Was There a Bright Side to the Evacuation of Greater New Orleans? National Bureau of Economic Research Working Paper Series, No. 13022. 


\section{Macrothink}

Journal of Asian Development

ISSN 2377-9594 2017, Vol. 3, No. 1

Yamane, T. (1967). Statistics: An Introductory Analysis (Second Edition ed.). New York: Harper and Row.

\section{Copyright Disclaimer}

Copyright for this article is retained by the author(s), with first publication rights granted to the journal.

This is an open-access article distributed under the terms and conditions of the Creative Commons Attribution license (http://creativecommons.org/licenses/by/3.0/). 